\title{
The Role of Oesophagogastroduodenoscopy in Avoiding Unnecessary Cholecystectomies in Patients with Gallstones and Upper Abdominal Discomfort
}

\author{
Mohamed Alshekhani* and Juned Gafoor Mustafa \\ Department of Medicine, University of Sulaimaniyah, Iraq
}

Submission: December 12, 2017; Published: February 02, 2018

"Corresponding author: Mohamed Alshekhani, Department of Medicine, University of Sulaimaniyah, Iraq, Email: shaikhanimohammad@googlemail.com

\begin{abstract}
Background: Cholelithiasis is a common condition, $10-20 \%$ of the population will develop gallstones, the incidence increases with age. Only about $30 \%$ of asymptomatic patients will warrant surgery during their lifetime. Dyspeptic symptoms due to other abdominal conditions such as PUD, IBS, Functional dyspepsia, IBS \& GERD are frequently attributed to Gallstones.
\end{abstract}

Aim of study: To assess the role of upper endoscopy in patients with gallstones in avoiding unnecessary cholecystectomies.

Patients and methods: 124 patients were included in sulaimanyah city hospitals from October 2015 to February 2017 complaining of upper GIT symptoms and U/S evidence of gallstones and an OGD is performed to exclude other possible explanation which may avoid unnecessary operation.

Results: Among 124 patient 99(79.8\%) were females and 25(20.2\%) were male; The mean age of studied patients was $46.4 \pm 14.5$ years. The OGD findings of patients with Gallstones were normal 63 (50.8\%), deudenal ulcer 24(19.4\%), non significant findings 24(19.4\%), reflux esophagi is $10(8.2 \%)$, gastrodudenitis $2(1.6 \%)$ and fungal esophagi is $(10.8 \%)$, There was $12(9.6 \%)$ patients in whom surgery decision was changed while in $112(90.4 \%)$ the surgery was done.

Conclusion: OGD is a very useful tool in the preoperative evaluation of patient with Gallstones with upper GIT symptoms.

Keywords: GIT; OGD; Gallstones

\section{Introduction}

Gallstone is one of the commonest problems in GE practice [1-3]. The prevalence is $5-10 \%$ mostly among female \& middle to elder age groups [4-7], rising in many countries including Iraq [8]. In England 70000 \& USA > 0.5 million cholecystectomies had done each year [9]. Risk factors include; Advancing age ,Multiple pregnancies, Obesity, repeated fluctuations in body weight, rapid weight loss $>1.5 \mathrm{~kg} /$ week, high dose estrogens \& Cholestyramine/fibrates [10-12]. Protective factors may include Moderate exercise, Coffee \& Moderate alcohol consumption [13$15]$.

Presentations of Gallstones include asymptomatic\& Symptomatic ones which include:

A. Biliary colic: a Moderate - Severe epigastria or right hypochondriac pain that last for 15 minutes to 6 hours or less than 24 hours, not associated with fever \& can be associated with nausea/vomiting, usually resolve spontaneously or by medications [16-18].

B. Symptomatic complications as acute pancreatitis, obstructive jaundice, cholecystitis $0.2-0.8 \%$ / annum, $0.3-1.2 \%$ if the stones are initially asymptomatic, $0.7-2 \%$ /annum if the stones are initially symptomatic, Other rare symptomatic complications include Acute cholangitis, Mucocele of gallbladder, Empyema of gallbladder, Gangrenous gallbladder, Biliary peritonitis, Porcelain gallbladder, Gallbladder cancer $[11,19,21,22]$.

Management includes:

A. Nonsurgical: Oral dissolution with bile acids successfully dissolved gallstones in an extremely limited patient population, especially in patients with symptomatic radiolucent gallstones < $15 \mathrm{~mm}$ within a functioning gallbladder. 
B. Laproscopiccholecystectomy (LC): results in a shorter hospital stay, speedier recovery, reduction of postoperative pain $\&$ better cosmetic results compared with open surgery [12,2325].

Indications for cholecystectomy for asymptomatic Gallstones may include:

a. Age: children \& young adults.

b. Very large stones $>3 \mathrm{~cm}$.

c. Thick walled gallbladder $>0.3 \mathrm{~cm}$.

d. Porcelain gallbladder

e. Large sessile polyps.

f. Race related like native American Indians [13,26-30].

4. Patients and Methods

A prospective study in sulaimanyahgovermental hospitals (KCGH, Shar teaching hospital \& Surgical teaching hospital). A total number of 124 patients with U/S diagnosed GSs \& upper GIT symptoms were referred to do OGD. A full history \&clinical exam carried out with emphasis on upper GIT \& Biliary symptoms. Patients were followed out to see in how many patients the decision to do operation was changed in the short term followup of our study period. Inclusion criteria: any adult with U/S evidence of GSs \& upper GIT symptoms.

Exclusion criteria: any case of complicated Gallstone including common bile duct stones, acutecholecystitis, pancreatitis, cholangitis.

\section{Results}

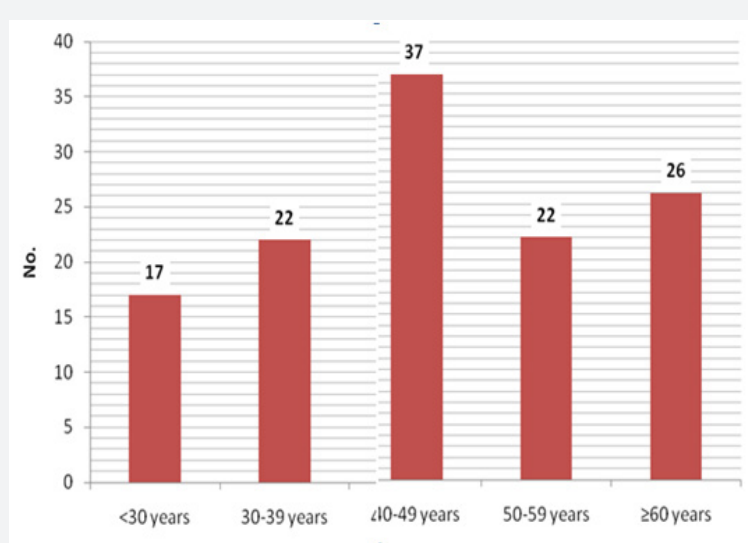

Figure 1: Age distribution of patients with Gallstones.

The presenting symptoms: Biliary colic $(72.6 \%)$, Epigastric pain $(22.6 \%)$ or other Dyspeptic symptoms $(3.2 \%)$ \& Heartburn $(1.6 \%)$.

The mean age of studied patients was $46.4 \pm 14.5$ years, $29.9 \%$ of them were $40-49$ years, $21 \%$ of them $\geq 60$ years, $17.7 \%$,3039 years, $17.7 \%, 50-59$ years \& $13.7 \%,>10$ years. Females were more than males with female to male ratio as 3.96:1(Figures 1-5 and Table 1).

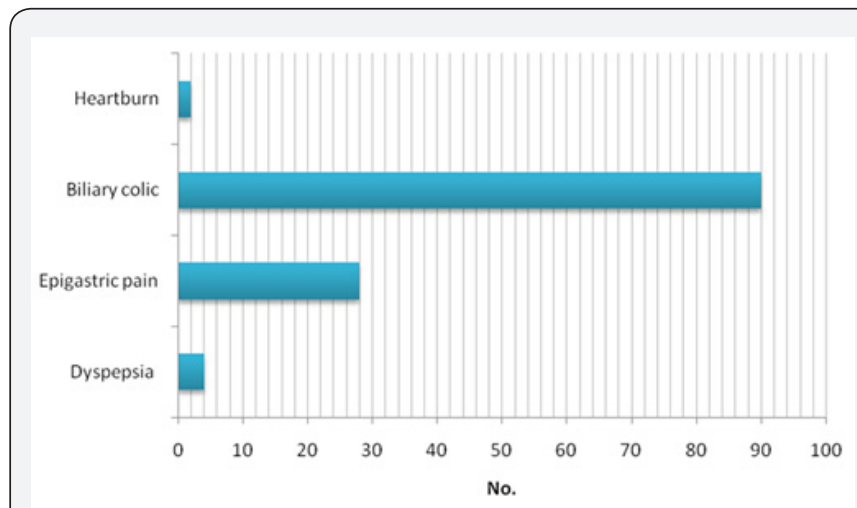

Figure 2: The presenting symptoms of patients with Gallstones. The OGD findings: Normal 63 (50.8\%)

Abnormal findings; $49.2 \%$ as below:

Deudenal ulcer 24 (19.4\%)

Non significant findings $24(19.4 \%)$

Reflux esophagitis 10 (8.2\%)

Gastrodudenitis $2(1.6 \%)$

Fungal esophagitis $1(0.8 \%)$.

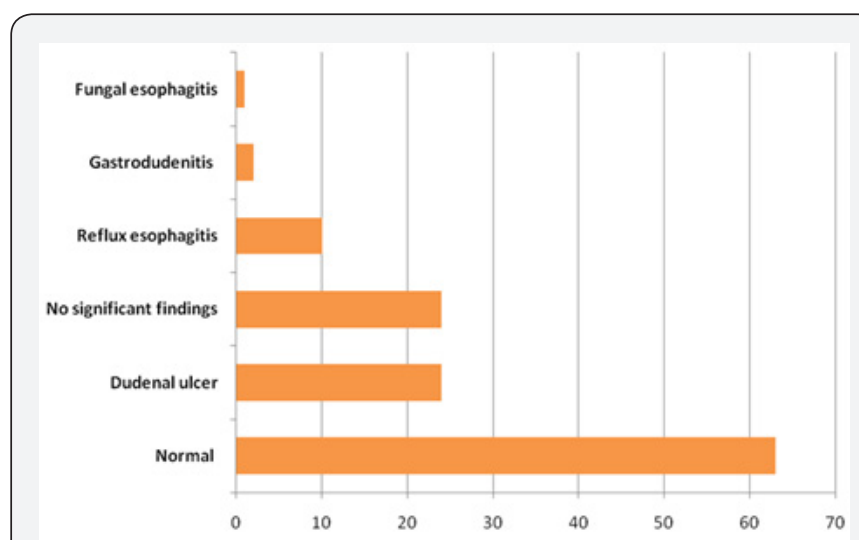

Figure 3: OGD findings of patients with Gallstones.

The change in decision for surgery was observed among $9.7 \%$ of patients with Gallstones after OGD. IN $90.3 \%$ there had been no change in decision.

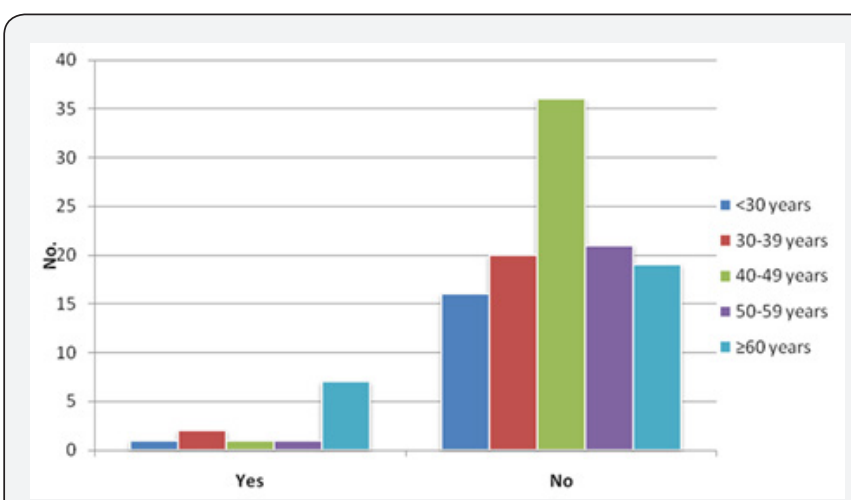

Figure 4: Distribution of age according to decision change.

There was a significant association between patients detected with duodenal ulcer by OGD \& decision change $(p=0.02)$ 


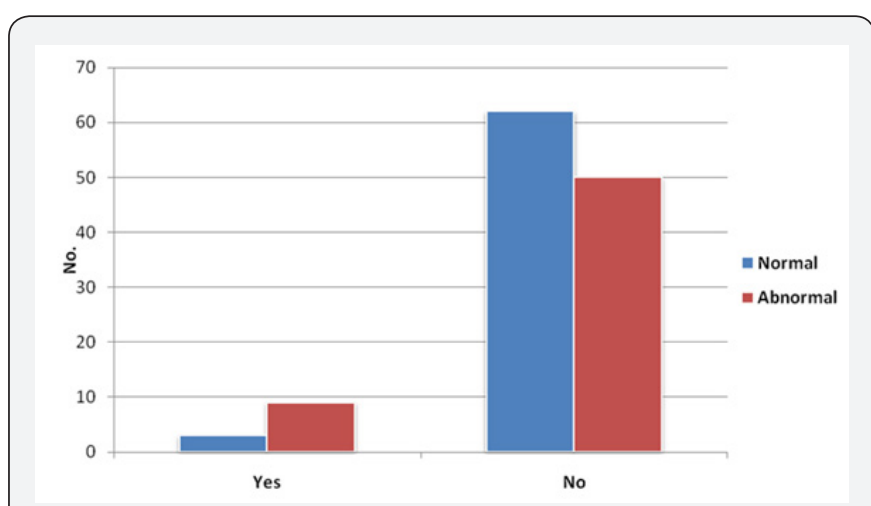

Figure 5: Distribution of OGD outcome according to decision change.

Table 1: Distribution of OGD findings of patients with Gallstones according to decision change.

\begin{tabular}{|c|c|c|c|c|c|c|}
\hline \multirow{2}{*}{ Variable } & \multicolumn{2}{|c|}{ No surgery } & \multicolumn{2}{|c|}{ Surgery } & \multirow{2}{*}{$\mathrm{X}^{2}$} & \multirow{2}{*}{$\mathbf{P}$} \\
\hline & No. & $\%$ & No. & $\%$ & & \\
\hline \multicolumn{5}{|c|}{ OCG findings } & & \\
\hline Normal & 1 & 8.3 & 62 & 55.4 & \multirow{6}{*}{$13.3^{*}$} & \multirow{6}{*}{0.02} \\
\hline Dudenal ulcer & 5 & 41.7 & 19 & 17 & & \\
\hline $\begin{array}{l}\text { No of significant } \\
\text { findings }\end{array}$ & 4 & 33.3 & 20 & 17.9 & & \\
\hline Reflux esphagitis & 1 & 8.3 & 9 & 8 & & \\
\hline Gastrodudenitis & 1 & 8.3 & 1 & 0.9 & & \\
\hline Fungal esphagitis & 0 & - & 1 & 0.9 & & \\
\hline
\end{tabular}

There was a significant association between Gallstone patients with abnormal OGD findings $\&$ decision change $(p=0.002)$.

\section{Discussion}

Our patients were 124 in number, female 99 (79.8\%), $25(20.2 \%)$ and a female to male ratio of $3.96 / 1$, similar prevalence observed in a study carried out in India [31-36]. In our study the OGD findings of patients with upper GIT symptoms and Gallstone were normal 63(50.8\%), deudenal ulcer $24(19.4 \%)$, non significant findings $24(19.4 \%)$, reflux esophagi is $10(8.2 \%)$, gastrodudenitis $2(1.6 \%)$ and fungal esophagi is $(0.8 \%)$. The results were near to results of a study carried out by Thybusch et al in Germany, which showed $50 \%$ of patients had pathological findings on OGD examination [37]. Another study in Germany recommend that OGD must be done before an elective cholecystectomy \&showed that out of 960 patients for elective cholecystectomy, 589 underwent gastro copy $56 \%$ had normal gastro copy [38].

In our study the change in decision for surgery was observed among $9.7 \%$ of patients with upper GIT symptoms and Gallstones after OGD while $90.3 \%$ of them had no change in decision \&underwent operation. The results of OGD findings changed decision in the management plan in $8.3 \%$ and $11.7 \%$ of patients in previously mentioned study by Thybusch et al. [37]
\& Rassek et al. [38]. A study in Poland showed that Pathological findings were identified in $1187(42 \%)$ patients \& the surgery was delayed for patients with ulcers until they finished their medical treatment, Sixteen patients had complete resolution of symptoms after medical treatment therefore cholecystectomy was not performed $[39,40]$. In a study done in Sudan included 108 patients with GSs \& OGD was done revealed different pathological findings in 61(56\%), Cholecystectomy was done for $82(76 \%) \& 26$ were treated conservatively [41]. A study in India [42] showed that in 89 patients the management plan had to be changed in $7.9 \%$ of patients based on the upper GI endoscopy findings ( $P$ value $<0.001$ ). In a meta-analysis of 12 cohort studies a total of 6317 patients with Cholelithiasis underwent OGD \& in $36.3 \%$ abnormality was found in OGD but only 3.8\% of patient surgery was avoided [43]. Another study by Yavorski et al. [43] recommend that patients who present with Cholelithiasis \& atypical abdominal pain undergo preoperative OGD, as they found that at least 9 per cent of the patients in their study had significant findings that altered their management. In a study in india in 2016,216 patient with Gallstone underwent OGD, showed $100 \%$ who underwent LC, had relief of symptoms in patients with normal OGD finding while those with significant OGD findings either not went through surgery in $10(4.6 \%)$ or when surgery was done they had more gradual relief of symptoms in 6 months follow-up [44]. A study in England suggested that OGD should be considered as a routine investigation before LC especially in those, who present with overlapping upper GI symptoms [45].

\section{Conclusion}

1. Gallstones are frequently silent \& upper GIT symptoms can be attributed to other pathologies in upper GIT.

2. OGD is a very useful tool which can be used in every case with Gallstone \& upper GIT complains especially those with atypical symptoms.

3. OGD before elective cholecystectomy can help avoid unnecessary surgeries.

4. Biliary colic was the most important symptom that predicted negative OGDs \& led to the decision of proceeding to surgery, so every effort should be done to take a good history of typical biliary colic in those patients.

\section{Recommendations}

1. We recommend evaluating patients with Gallstones very carefully to avoid doing un-necessary LC.

2. We highly recommend OGD as an appropriate evaluation of patients planned for elective cholecystectomies.

\section{References}

1. Everhart J (2008) The burden of digestive diseases in the United States.

2. Centers for Disease Control and Prevention. Discharges with at least one procedure in nonfederal short-stay hospitals, by sex, age, and selected procedures: United States, selected years 1990 through 20092010, www.cdc.gov/nchs/hus/contents2012.htm\#098. 
3. Health and Social Care Information Centre. Hospital episode statistics, Admitted patient care, England-2012-13.

4. Karmacharya A, Malla BR, Joshi HN, Gurung RB, Rajbhandari M (2013) The predictve value of pre-operatve symptoms including upper gastrointestnal endoscopy before laparoscopic cholecystectomy for electve symptomatc cholecystolithiasis. Kathmandu Univ Med J 44(4): 300-304.

5. Huang J, Chang CH, Wang JI, Kuo HK, Zin JW, Shan WY (2009) Natonwide epidemiological study of several gallstone disease in Taiwan. BMC Gastroenterol 9: 63

6. Everhart JE, Kharre M, Hill M, Maver KR (1999) Prevalence and ethnic differences in gallbladder diseases in the United States. Gastroenteroscopy 117(3): 632-639.

7. Conte D, Fraquelli M, GiuntaM, Cont CB (2011) Gall stones and Liver disease; an overview. J Gastrointestn Liver Dis 20(1): 9-11.

8. (2001) Changing Pattern and Incidence of Gallstone Diseases in AlKadhymia Teaching Hospital, Bashar A Abdul Hassan, Dept. of Surgery, College of Medicine, Al-Nahrain University, IRAQI J MED SCI. 9(2).

9. Diehl AK (1991) Epidemiology and natural history of gallstone disease. Gastroenterol Clin North Am. 20(1): 1-19.

10. Weinster RL, wilsonLJ, lee LJ (1995) Medically safe weight loss for treatment of obesity: a guideline based on the risk of gallstone formation. AM J MED 98(2): 115-117.

11. Atilli AF, Capocaccia R, CarulliN, Festi D, Roda E, et al. (1997) Factors associated with gallstone disease in theMICOLexperience. Multicenter italian study on epidemiology of cholelithiasis. Hepatology 26(4): 809818

12. Leitzman MF, Rimm EB, Willet WC, Grodstein F, Colditz GA, et al. (1999) Recreation physical activity and the risk of cholecystectomy in women N Engl J Med 341(11): 777-784.

13. Veysey MJ, Thomas LA, Mallet AI, Jenkins PJ, Besser Gm, et al. (1999) Prolonged large bowel transit increase serum deoxycholic acid: a risk factor for octreotide induced gallstone. Gut 44(5): 675-681.

14. Heaton KW (2000) Epidemiology of gallbladder disease-role of intestinal transit. Alimentpharmacolther 14(2): 9-13.

15. Leitzman MF, Rimm EB, Willet WC, Stampfer MJ, Coldtz GA, et al. (1999) A prospective study coffee consumption and the risk of gallstone in men. JAMA 281(22): 2106-2112.

16. Caroli-rose FX, Le Gall P, Puliese P, Delabre B, Demarquay JF, et al (2001) Role of fibrates and HMG-COA reductase inhibitors in gallstone formation; epidemiological study in an unselected population. Dig Dis Sci 46(3): 540-544.

17. (2005) First principles of gastroentrology fifth edition. In: ABR Thomas, EA Shaffer (Eds.), Janssen-Ortho, canada.

18. (2015) Harrisons principles of internal medicine $19^{\text {th }}$ edition $1-2$.

19. WGO Practice Guideline: Asymptomatic Gallstone Disease, core team In: AG Johnson, M Fried, GNJ Tytgat, JH, Krabshuis Special Advisors: Roque Saenz, Martin Carey, SP Lee.

20. Heaton KW, Braddon FE, Mountford RA, Hughes AO, Emmett PM (1991) Symptomatic and silent gall stones in the community. Gut 32(3): 316320

21. Capocaccia L, Giunchi G, Pocchiari F (1984) Prevalence of gallstone disease in an Italian adult female population. Rome Group for the Epidemiology and Prevention of Cholelithiasis (GREPCO). American Journal of Epidemiology 119(5): 796-805.

22. Fendrick AM, Gleeson SP, Cabana MD, Scwartz JS (1993) Asymptomatic gallstones revisited. Is there a role for laparoscopic cholecystectomy? Arch Fam Med 2(9): 959-68.
23. Kurinchi S Gurusamy (2014) Gallstones. Clinical Review 348: 2669.

24. Petroni ML, Jazrawi RP, Pazzi P, Lanzini A, Zuin M, et al. (2001) Ursodeoxycholic acid alone or with chenodeoxycholic acid for dissolution of cholesterol gallstones: a randomized multicentre trial. The British-Italian Gallstone Study group. Aliment Pharmacol Ther 15(1): 123-128.

25. Hood KA, Gleeson D, Ruppin DC, Dowling RH(1993) Gallstone recurrence and its prevention: the British/Belgian Gall Stone Study Group's post dissolution trial. Gut 34(9): 1277-1288.

26. (1992) Gallstones and laparoscopic cholecystectomy. NIH Consensus Statement 10(3): 1-28.

27. Tornqvist B, Stromberg C, Persson G, Nilsson M (2012) Effect of intended intraoperative cholangiography and early detection of bile duct injury on survival after cholecystectomy: population based cohort study. BMJ 345: 6457.

28. Gurusamy KS, Davidson BR (2010) Surgical treatment of gallstones. Gastroenterol Clin North Am 39(2): 229-244.

29. Department of Health. NHS reference costs 2012 to 2013. www.gov.uk/ government/ publications/nhs-reference-costs-2012-to-2013.

30. Keus F, Dejong JAF, Goosze HG, Van Larrhove CJHM (2006) Laparascopic versus open cholcystectomy for patients with symptomatic colelithiasis. Chocrane database sys rev (4): CD006231.

31. Patino JF, Quintero GA (1998) Asymptomatic cholelithiasis revisited World J Surg 22(11): 1119-1124.

32. Srikanth G, Kumar A, Khare R, Siddappa L, Gupta A, Sikora SS, et al (2004) Should laparoscopic cholecystectomy be performed in patients with thick walled gall bladder? J Hepatobiliary Pancreat Surg 11(1): 40-44.

33. Diehl AK (1983) Gallstone size and the risk of gall bladder cancer. JAMA 250(17): 2323-2326.

34. Vitetta L, Sali A, Little P, Mrazek L (2000) Gallstones and gall bladder carcinoma. Aust N Z J Surg 70(9): 667-673.

35. Lowenfels AB, Lindstrom CG, Conway MJ, Hastings PR (1985) Gallstones and risk of gallbladder cancer. J Natl Cancer Inst 5(1): 77-80.

36. Kolla V, Charles N, Datey S, Mahor D, Gupta A, Malhotra S (2016) Upper gastrointestinal endoscopy prior to laparoscopic cholecystectomy: a clinical study at a tertiary care centre in central India. Int Surg J 3(2): 637-642.

37. Thybusch A, Schaube H, Schweizer E, Gollnick D, Grimm H (1996) [Significant value and therapeutic implications of routine gastroscopy before cholecystectomy]. J Chir (Paris) 133(4): 171-174.

38. Rassek D, Osswald J, Stock W (1988) [Routine gastroscopy before cholecystectomy]. Chir`urg 59(5): 335-337.

39. Sosada K, Zurawinski W, Piecuch J, Stepien T, Makarska J (2005) Gastroduodenoscopy: a routine examination of 2,800 patients before laparoscopic cholecystectomy. Surg Endosc 19(8): 1103-1108.

40. Mohamed Toum Musa M Ibrahim, Randa Zaki A M Khair, El-Hadi Y Mohamed, AbdelMagid M Massaad. Upper gastrointestinal endoscopic fndings in patients with gallstone disease. University of Khartoum, Khartoum Teaching Hospital, Omdurman Islamic University.

41. Indrajit R, Jugindra S, Chandragupta C (2016) Role of upper gastrointestinal endoscopy in patients with symptomatic gallstone disease - a prospective, descriptive study. Indian Journal of Medical Research and Pharmaceutical Sciences 3(8).

42. Mark PL, Wietske K, Cihan Özdemir, Gert P Westert, Cornelis JHM van Laarhoven, Joost PH Drent. EGD in patients referred for cholecystectomy: a systematic review and meta-analysis. 
43. Yavorski CC, Acosta JA, Ragland JJ (1995) Precholecystectomy esophagogastroduodeno- scopy: is it of value? Am Surg 61(12): 10321034.

44. Rashid F, Rashid N, Waraich N, Ahmed J, Iftikhar SY (2010) Role of routine oesophagogastroduodenoscopy before cholecystectomy. International Journal ofSurgery 8(3): 236-238.

45. http://www.intechopen.com/books/endoscopy-of-gi-tract.intech
This work is licensed under Creative

Commons Attribution 4.0 License

DOI: 10.19080/ARGH.2018.08.555747

\section{Your next submission with JuniperPublishers will reach you the below assets}

- Quality Editorial service

- Swift Peer Review

- Reprints availability

- E-prints Service

- Manuscript Podcast for convenient understanding

- Global attainment for your research

- Manuscript accessibility in different formats

( Pdf, E-pub, Full Text, audio)

- Unceasing customer service

Track the below URL for one-step submission https://juniperpublishers.com/online-submission.php 